\title{
Long-eared Myotis Found in Saskatchewan
}

by R. W. Nero, Saskatchewan Museum of Natural History

Fred Bock (summer field assistant, S.M.N.H.) collected two bats with .22 bird-shot in the valley of the South Saskatchewan River, north of Main Centre, Sask., late in the evening of June 24 and 25, 1960. One of these bats, which were preserved in alcohol, is a female Smallfocted Myotis (Myotis subulatus), and is the third pnovincial record of this species (see Blue Jay, 17:169). The other bat has been identified as a male Long-eared Myotis (Myotis evotis), a species listed as hypcthetical on the basis of its occurrence in adjacent regions (Beck, 1958. A Guide to Saskatchewan Mammals). Identification of this bat as Myotis evotis has been confirmed by Prof. W. H. Burt (University of Michigan Museum of Zoclogy). Measurements of the preserved specimen are: total length $-88 \mathrm{~mm}$, length of hind foct -8 , length of ear from ncitch-19, length of forearm-38, length of third finger-63, length of tragus from notch-12, greaitest length of skull-16.7, interorbital constriction. -4.3, mastoidal breadth-7.5, breadth of ibraincase-8, greatest height of skull-6.8, and alveolar length of maxillary tooth row-6.3. These measurements may be useful to mammalogists concerned with the close similarity between this species and Keen's Myotis (Myotis keenii) anather small brown bat with large eans which has been recorded in north- central Saskatchewan and which is to be expected from there throughout the southeastern pontion of the province. Both species are represented in Saskatchewan only by single specimens; additional collecting will be necessary in order to determine their exact ranges.

The Long-eared Myotis ranges from southern British Columbia, Alberta, southwestern Saskatcherwan, western North Dakota and South Dakota south to central Mexico. It is an inhabitant of thinly forested to semi-desert areas and appears to be unccmmon. It prefers to roost singly or in small clusters in secluded niches of buildings and probably in trees. (Haill and Nelson, 1959. The Mammals of North America). According to W. W. Dalquest (1948. Mammals of Waishington) the species apparently does its hunting late at night and is therefore difficult to collect. As might be expected little is known of the habits of this bat. This species is another member of a group of western animals found in Saskatchewan in the scuthwestern corner. The area of the South Saskatchewan River valley where this bat was found is generally sparsely vegetated and arid. There are many bare rocky exposures, cliffs and ravines which offer suitable hiding places for bats. Olivebacked Pocket Mice (Perognathus fasciatus) and Spade-foot Toads (Scaphiopus bombifrons) have been collected in the same locality.
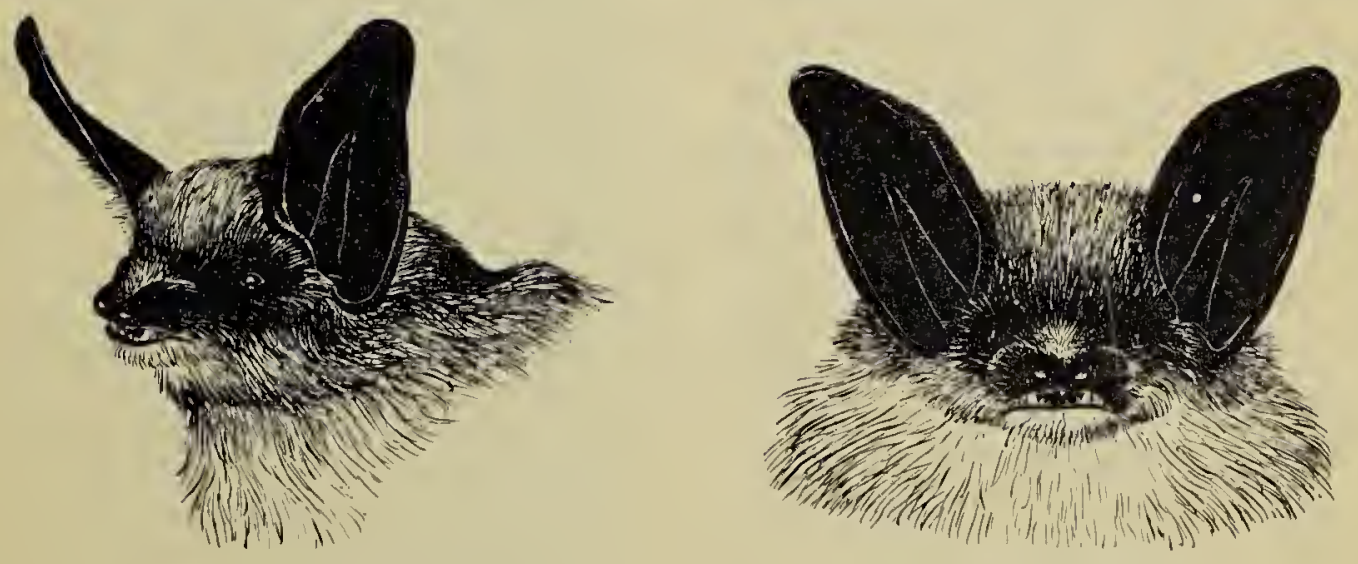

Drawing trom preserved specimen by Ralph Carson Long-eared Myotis. natural size. 